\title{
Stimulatory effect of repeated treatment with lipopolysaccharide on a key enzyme of the kynurenine pathway in both genders in rats Stimulačný vplyv opakovaného podávania lipopolysacharidu na klúčový enzým kynurenínovej dráhy u samcov a samičiek potkana
}

Received 1 August, 2016, accepted 5 August, 2016

\begin{abstract}
The neuroprotective or neurotoxic effects of the products of the kynurenine pathway of tryptophan metabolism highly depend on the action of kynurenine-3-monooxygenase (KMO). The present results show increased concentrations of the KMO in the plasma of rats repeatedly exposed to an immune challenge. Increased concentrations of this key enzyme are likely to cause a shift of kynurenine pathway towards enhanced production of neurotoxic metabolites.

Slovak Neuroprotektívny a neurotoxický účinok produktov kynurenínovej dráhy metabolizmu tryptofánu je vysoko závislý od pôsobenia abstract kynurenín-3-monooxygenázy (KMO). Získané výsledky dokazujú zvýšenú plazmatickú koncentráciu KMO u potkanov opakovane vystavených aktivácii imunitného systému. Zvýšené koncentrácie tohto klúčového enzýmu môžu spôsobit posun kynurenínovej dráhy smerom k zvýšenej produkcii neurotoxických metabolitov.
\end{abstract}

Keywords Immune challenge-Kynurenine-3-monooxygenase-Gender

Klúčové imunitná aktivácia-kynurenín-3-monooxygenáza-pohlavie slová:

\section{INTRODUCTION}

Lipopolysaccharide (LPS) is an endotoxin of the outer membrane of Gram-negative bacteria Escherichia coli. Repeated administration of LPS can be used as a model of chronic stress and also as a model for immune system activation. Among others, the administration of LPS leads to activation of the kynurenine pathway of tryptophan metabolism (Kubesova et al. 2015). The kynurenine pathway consists of two functionally distinct branches that generate several neuroactive metabolites. Under basal conditions, kynurenine metabolism favours the formation of neuroprotective kynurenic acid. Disruptions in homoeostasis can shift the balance towards an increased production of the neurotoxic quinolinic acid. Kynurenine-3monooxygenase $(\mathrm{KMO})$ is a key enzyme involved in regulating the production of these two metabolites. Changes in KMO expression or activity may contribute to the development of neurodegenerative, neuropsychiatric and neurodevelopmental diseases (Parrott and O'Connor, 2015).

The aim of the present study was to test the hypothesis that repeated treatment with LPS has an impact on plasma concentrations of KMO. To our knowledge, there is no information on gender differences in LPS-induced activation of the kynurenine pathway. Therefore, the present experiments were performed in both male and female rats.

\section{MATERIAL AND METHODS}

Sprague-Dawley rats were treated either with LPS in increasing doses (to prevent the development of tolerance) 
for 5 days $(50-200 \mu \mathrm{g} / \mathrm{kg}$ ) or vehicle, thus simulating a shortterm inflammatory state. All procedures were approved by the Animal Health and Animal Welfare Division of the State Veterinary and Food Administration of the Slovak Republic. Two hours after the last injection, the animals were quickly decapitated and blood was collected. Plasma concentrations of KMO were measured by an enzyme-linked immunosorbent assay (ELISA) kit according to the manufacturer's instructions (CSB-EL012475RA, Cusabio). The sensitivity of the assay was $3.9 \mathrm{pg} / \mathrm{ml}$ with the intra-assay and inter-assay coefficient of variation of $<8 \%$ and $<10 \%$, respectively. The results were analysed by two-way ANOVA for factors treatment and gender.

\section{RESULTS}

The activation of the immune system by a repeated treatment with LPS was confirmed by a decrease in body weight gain and increased mRNA levels of proinflammatory cytokines (data not shown). The analysis by two-way ANOVA revealed a significant main effect of treatment $\left(F_{(1.28)}=74.915 ; p<\right.$ $0.001)$. Concentrations of $\mathrm{KMO}$ in plasma were significantly higher in rats repeatedly treated with LPS compared to those in vehicle-treated animals (Fig. 1). No statistically significant differences were observed for gender.

\section{DISCUSSION AND CONCLUSION}

The present findings confirmed our hypothesis and showed that repeated treatment with the endotoxin LPS increases plasma concentrations of $\mathrm{KMO}$, a key enzyme of the kynurenine pathway of tryptophan metabolism. This activation was present in both genders.

The observation of enhanced levels of KMO is consistent with previous studies describing the effects of acute administration of LPS. Single peripheral injection of LPS induced a robust increase in the KMO gene expression in the rat brain cortex and hippocampus (Connor et al. 2008). KMO mRNA levels were also increased in isolated microglia of mice after acute treatment with LPS (Corona et al. 2010). No studies evaluating the concentrations or gene expression of KMO under repeated LPS treatment have been reported in the available literature. Another factor that could modify the action of LPS is gender.

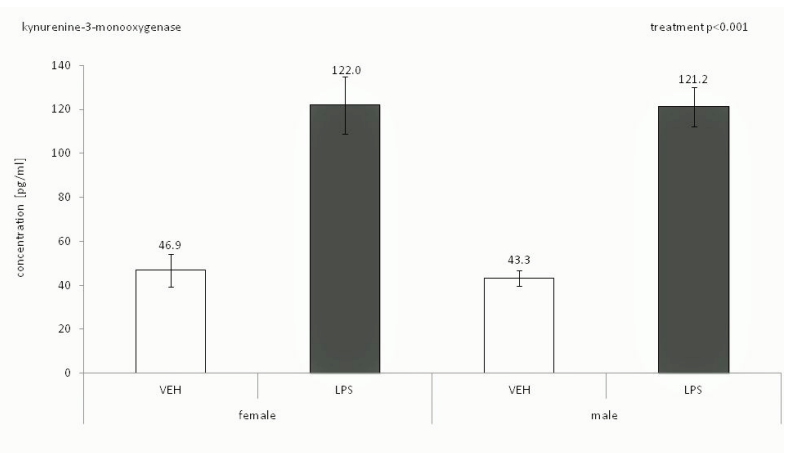

Figure 1. Concentrations of KMO in plasma of rats treated with increasing doses of LPS or vehicle for 5 days. Results are expressed as means \pm SEM

Indeed, exposure to stressors, including LPS, is known to induce a higher neuroendocrine activation in females compared to males (Daneva et al. 1993; Jezová et al. 1996). The present study shows that the stimulatory effect of repeated LPS on KMO protein is not gender-dependent. A small number of clinical studies comparing male and female patients failed to show gender differences or revealed higher concentrations of kynurenines in plasma in men than in women (Theofylaktopoulou et al. 2013). In spite of the existence of gender differences in serotonin synthesis in both humans and animals, no information on gender differences in any of the metabolites or enzymes of kynurenine pathway is available.

In conclusion, the present results support the view of an enhanced production of neurotoxic metabolites of kynurenine pathway after repeated immune challenge. Alterations in the kynurenine pathway and the changing levels of its metabolites have been considered as factors contributing to the pathogenesis of depression (Franklin et al. 2015). Thus, it may be suggested that repeated activation of immune system may contribute to the development of mood disorders.

\section{ACKNOWLEDGEMENT}

This research was supported by grants of VEGA 2/0128/14 and APVV-14-0840.
[1] Connor TJ, Starr N, O'Sullivan JB, Harkin A. Induction of indolamine 2,3-dioxygenase and kynurenine 3-monooxygenase in rat brain following a systemic inflammatory challenge: a role for IFNgamma? Neurosci Lett. 2008;441:29-34.

[2] Corona AW, Huang Y, O'Connor JC, Dantzer R, Kelley KW, Popovich PG, Godbout JP. Fractalkine receptor (CX3CR1) deficiency sensitizes mice to the behavioral changes induced by lipopolysaccharide. J Neuroinflammation. 2010;7:93.
[3] Daneva T, Spinedi E, Hadid R, Jacquier MC, Giacomini M, Gaillard RC. Transient sex-related changes in the mice hypothalamopituitary-adrenal (HPA) axis during the acute phase of the inflammatory process. Mediators Inflamm. 1993;2:123-127.

[4] Franklin M, Hlavacova N, Babic S, Pokusa M, Bermudez I, Jezova D. Aldosterone Signals the Onset of Depressive Behaviour in a Female Rat Model of Depression along with SSRI Treatment Resistance. Neuroendocrinology. 2015;102:274-287. 
[5] Jezová D, Juránková E, Mosnárová A, Kriska M, Skultétyová I. Neuroendocrine response during stress with relation to gender differences. Acta Neurobiol Exp (Wars). 1996;56:779-785.

[6] Kubesova A, Tejkalova H, Syslova K, Kacer P, Vondrousova J, Tyls F, Fujakova M, Palenicek T, Horacek J. Biochemical, Histopathological and Morphological Profiling of a Rat Model of Early Immune Stimulation: Relation to Psychopathology. PLoS One. 2015;10:e0115439.

[7] Parrott JM, O'Connor JC. Kynurenine 3-Monooxygenase: An Influential Mediator of Neuropathology. Front Psychiatry. 2015;6:116.

[8] Theofylaktopoulou D, Midttun $\varnothing$, Ulvik A, Ueland PM, Tell GS, Vollset SE, Nygård O, Eussen SJ. A community-based study on determinants of circulating markers of cellular immune activation and kynurenines: the Hordaland Health Study. Clin Exp Immunol. 2013;173:121-130. 